\title{
Obituary
}

\section{Marc Richelle (28th February 1930 - 6th January 2021)}

\author{
John Wearden \\ School of Psychology, University of Keele, Keele, ST5 5BG, UK \\ Division and Neuroscience and Experimental Psychology, The University of Manchester, \\ Oxford Road, Manchester, M13 9PL, UK \\ E-mail: j.h.wearden@keele.ac.uk
}

Marc Richelle was born in Verviers, and died nearly 91 years later, at Goesnes in Belgium. He was founding Professor of Experimental Psychology at the University of Liège in Belgium, and held this chair from 1965 until his retirement in 1995.

Like many European psychologists of his generation, his first degree was not in Psychology. He obtained a Master's in Philosophy and Letters from the University of Liège in 1952, and this may have resulted in his first publication, an analysis of a famous, and famously obscure, poem by Gérard de Nerval, "El Desdichado" (Richelle, 1952). This was followed by another Master's degree, this time from Geneva, where he was influenced not only by Piaget, but perhaps even more by the lesser-known figure of André Rey, with whom he collaborated on research on attention, as well as a project on North African Jewish children who emigrated to Israel. In the 1950s he also worked on cultural anthropology in Central Africa. In 1958 and 1959 he studied at Harvard, where he was introduced to Skinner's methods and ideas, which shaped much of his later career. After a doctorate from Liège in 1959 he obtained a position as a Lecturer at the same University, in the Faculty of Philosophy and Letters.

He began the experimental work for which he later became well-known under the auspices of the Liège Department of Pharmacology, where he obtained laboratory space and was able to develop a unit specializing in animal operant conditioning, with what may have been the first appearance of Skinner boxes on the European continent. The fruits of this laboratory during the 1960s were 
twenty or so publications on effects of drugs on animal behaviour, some with Ovide Fontaine, a psychiatrist who was a central figure in developing behavioural therapies in Belgium (e.g., Fontaine \& Richelle, 1969). In 1965, Richelle became Professor of Experimental Psychology in the newly created Faculty of Psychology.

The 1970s saw Richelle involved in important work on the temporal regulation of behaviour in a variety of animal species, along with students and collaborators who were later to become celebrated in the field of timing in their own right, notably Françoise Macar and, particularly, Helga Lejeune. Helga Lejeune worked in the Liège laboratory for many years and was responsible for most of the highly ingenious technical work on the sometimes unusual species they studied there. Much of their research was reviewed in Richelle and Lejeune's magisterial volume Time in Animal Behaviour (1980). Although others made some contributions, Lejeune, and Richelle himself, were responsible for the majority of the text, which surveyed practically everything known about laboratory studies of animal timing up until that time, including much unpublished work from the Liège laboratory. Not only does it review methods and results obtained with commonly used temporally defined schedules of reinforcement, but also cross-species comparisons (see also Richelle \& Lejeune, 1977), and less common topics such as the effects of external cues on animal timing, and the nature and role of collateral behaviours. This monument of detailed scholarship can be read with profit by anyone interested in animal timing even today and represents one of the high points of Richelle's technical work in experimental Psychology. The laboratory he founded continued to produce experimental and theoretical work on animal timing for more than 20 years after the publication of Time in Animal Behaviour (e.g., Lejeune et al., 1998), and is still active in psychopharmacology, the area which Richelle initiated. It always offered a generous welcome to visitors outside the immediate Francophone area, including Armando Machado from Portugal, with whom Richelle wrote an article on behavioural variability (Boulanger et al., 1987), and myself, as well as to many from Belgium and France, such as Viviane Pouthas and her student Sylvie Droit-Volet.

Marc Richelle was not only a laboratory scientist. From the 1960s onwards he was a tireless, but not uncritical, advocate of "scientific", notably radical behaviourist, approaches to Psychology, at the time little known in European psychological circles. Not only did he possess possibly the first Skinner boxes in Europe, but he also told people what to do with them in publications explaining the nature of operant conditioning (e.g., Richelle, 1966). Several of his writings tried to explain Skinner's positions to audiences perhaps ill-prepared culturally and philosophically to accept them (e.g., Richelle, 1977), culminating in a 'reappraisal' of Skinner's work (Richelle, 1995). His early training in literature and linguistics also led him to produce a book on language acquisition (Richelle, 1972), attempting 
to provide some perspective on the famous controversy between Chomsky and Skinner concerning Skinner's approach to verbal behaviour.

More recently, Richelle was stimulated by the controversy surrounding Sokal and Bricmont's (1997) Impostures Intellectuelles to speak and write about the scientific status of the 'human sciences' (Richelle, 1998). Readers who understand French can benefit from a radio interview with Richelle on this topic, at https://lacademie.tv/conferences/ interview-de-marc-richelle-sciences-humaines-n-y-a-t-il-que-des-imposteurs-

Marc Richelle was also an indefatigable champion of international collaboration, involving conferences and participation in an extensive Erasmus network, as well as being a participant on numerous academic committees, in Belgium and abroad. He received five honorary doctorates, as well as the Prix Solvay, Belgium's highest scientific award. His retirement was commemorated by an edited volume (Lejeune et al., 1995) which shows the scope of Richelle's psychological interests, and in a more recent interview conducted with Céline Clément (Clément, 2016) he discusses some of the influences on his work. In the table of contents of the magazine in which this interview appears, he appears as "Marc Richelle, France", which must surely have raised an ironic Richellian eyebrow.

For many, Marc Richelle was the very image of a European Professor of his generation: urbane, multilingual, cultured, internationally-minded, personally influential, and familiar with the corridors of academic power. He was also, as I can attest, a lover of good food and wine. Those who knew him could raise a glass in his memory.

\section{References}

Boulanger, B., Ingebos, A.-M., Lahak, M., Machado, A., \& Richelle, M. (1987). Variabilité comportementale et conditionnement operant chez l'animal: Revue critique. Année Psychol., 87, 417-434.

Clément, C. (2016). Profile of Marc Richelle. Operants, quarter IV, 22-25.

Fontaine, O., \& Richelle, M. (1969). Etude comparative chez le rat des effets de la chlorpromazine et du chlordiazepoxide sur un série de programmes à renforcement positif et à renforcement negatif. Psychol. Belg., 9, 17-29.

Lejeune, H., Cornet, S., Ferreira, M.A., \& Wearden, J.H. (1998). How do Mongolian gerbils (Meriones unguiculatus) pass the time? Adjunctive behavior during temporal differentiation in gerbils. J. Exp. Psychol. Anim. Behav. Processes, 24, 352-368. https://doi.org/10.1037/0097-7403.24.3.352. Lejeune, H., Macar, F., \& Pouthas, V. (Eds). (1995). Des Animaux et des hommes: Hommage à Marc Richelle. Paris, France: Presses Universitaires de France.

Richelle, M. (1952). Gérard de Nerval: El Desdichado. Analyse textuelle. Rev. Lang. Vivantes, 17, 205-211.

Richelle, M. (1966). Le conditionnement operant. Neuchatel, Switzerland: Delachaux et Niestlé.

Richelle, M. (1972). L'acquisition du langage. Brussels, Belgium: Dessart-Mardaga.

Richelle, M. (1977). Skinner ou le péril behavioriste. Brussels, Belgium: Mardaga.

Richelle, M. (1995). B.F. Skinner: A reappraisal. London, UK: Taylor and Francis. 
Richelle, M. (1998). Défense des sciences humaines: Vers une désokalisation? Brussels, Belgium: Mardaga.

Richelle, M., \& Lejeune, H. (1977). L'animal et le temps. In P. Fraisse (Ed.), Du temps biologique au temps psychologique, pp. 73-128. Paris, France: Presses Universitaires de France.

Richelle, M., \& Lejeune, H. (1980). Time in Animal Behaviour. Oxford, UK: Pergamon Press.

Sokal, A., \& Bricmont, J. (1997). Impostures Intellectuelles. Paris, France: Editions Odile Jacob. 